\title{
The Adsorption Capacity, Pore Structure, and Thermal Behavior of the Modified Clay Containing SSA
}

\author{
Haijun Lu, Qian Zhang, Yiqie Dong, Jixiang Li, and Xiong Zhang \\ Institute of Poromechanics, Wuhan Polytechnic University, Wuhan 430023, China \\ Correspondence should be addressed to Haijun Lu; lhj_whpu@163.com
}

Received 28 December 2015; Revised 9 May 2016; Accepted 31 May 2016

Academic Editor: Patrice Berthod

Copyright ( 92016 Haijun Lu et al. This is an open access article distributed under the Creative Commons Attribution License, which permits unrestricted use, distribution, and reproduction in any medium, provided the original work is properly cited.

\begin{abstract}
Sewage sludge ash (SSA) was created by burning municipal sludge. The potential of clay containing 1 or 3 or $5 \%$ SSA was assessed for use as a landfill liner-soil material. Batch adsorption, low temperature $\mathrm{N}_{2}$ adsorption, and TG-DTA tests were performed to evaluate the adsorption capacity, micropore structure, thermostability, and components of soils under $\mathrm{Cr}(\mathrm{VI})$ and $\mathrm{Pb}$ (II) chemical solutions. With the increasing amount of SSA in modified clay, the adsorption capacity of $\mathrm{Cr}(\mathrm{VI})$ and $\mathrm{Pb}(\mathrm{II})$ to the modified clay increases gradually. After absorption, the pore size of modified clay ranges from $2 \mathrm{~nm}$ to $8 \mathrm{~nm}$. With the increasing amount of absorption, the pore volume decreases and the specific surface area increases. With the increasing of adsorption concentration of $\mathrm{Cr}(\mathrm{VI})$ and $\mathrm{Pb}$ (II), the mass loss percentage of modified clay increases to $23.4 \%$ and $12.6 \%$, respectively. The modified clay containing SSA may be used as a good barrier material to attenuate contamination of $\mathrm{Cr}(\mathrm{VI})$ and $\mathrm{Pb}(\mathrm{II})$ in landfills.
\end{abstract}

\section{Introduction}

Leachate from solid-waste landfills was found to contain a number of heavy metal ions. These heavy metal ions may enter the aquifer underlying the landfill and thereby pose a potential threat to human health [1-3]. To prevent the transport of contaminants present in the leachate, the liner system composed of the compacted clay is widely applied to design of the landfill [4]. However, many heavy metal ions can pollute groundwater by diffusion through a block liner. Hence, there is a crucial need for the development of a new landfill liner that can effectively prevent the transport of heavy metal ions $[5,6]$.

Sewage sludge is the inevitable by-product of sewage deposition. Currently, the global annual output of wet sewage [7] is $2.241 \times 10^{-7} \mathrm{t}$. Wet sewage is usually disposed by concentrate dewatering and then stored in security landfills. In addition to a few organic substances, wet sewage contains inorganic substances [8-10] that are rich in silicon and aluminum. Studies show that dewatered sludge can be transformed into granular ash after high temperature burning. Granular ash is a porous material [11-13] with a high specific surface area and ion-exchange capacity. Granular ash is considered a mineral admixture, which enhances the mechanical properties of concrete. Granular ash mixed with clay can be used as a modified landfill liner material that can absorb pollutants in leachate. However, studies have not been conducted on this material.

This study aims to evaluate the adsorption capacity, pore structure, and phase composition of modified clay as new landfill liner material. Batch adsorption tests were used to explore the adsorption capacity of $\mathrm{Cr}(\mathrm{VI})$ and $\mathrm{Pb}(\mathrm{II})$ to the modified clay and decide the additive amount of sewage sludge ash (SSA). Low temperature $\mathrm{N}_{2}$ adsorption tests were used to analyze pore structure of the modified clay. TGDTA tests were performed to explore the thermostability and components of the modified clay.

\section{Testing Materials and Methods}

2.1. Testing Materials. The clay and sewage sludge used in the tests are obtained from a construction site and the Hanxi sewage treatment plant in Wuhan, China, respectively. Clay was dug from a depth of $2.5 \sim 3.0 \mathrm{~m}$. The soil was kept in a sealed bag to avoid contamination. The basic physical properties of the clay are listed in Table 1, and the chemical compositions of the clay are listed in Table 2. This type of 
TABLE 1: The basic physical properties of the clay in the tests.

\begin{tabular}{|c|c|c|c|c|c|c|c|c|c|}
\hline \multirow{2}{*}{ Proportion } & \multirow{2}{*}{$\begin{array}{l}\text { Specific surface } \\
\text { area } / \mathrm{m}^{2} / \mathrm{g}\end{array}$} & \multirow{2}{*}{$\begin{array}{l}\text { Natural moisture } \\
\text { content } / \%\end{array}$} & \multirow{2}{*}{$W_{L} / \%$} & \multirow{2}{*}{$W_{p} / \%$} & \multirow{2}{*}{$I_{p}$} & \multicolumn{4}{|c|}{ Particle size distribution/\% } \\
\hline & & & & & & $>0.05 \mathrm{~mm}$ & $0.05 \sim 0.005 \mathrm{~mm}$ & $0.005 \sim 0.002 \mathrm{~mm}$ & $<0.002 \mathrm{~mm}$ \\
\hline 2.65 & 86.53 & 21.2 & 48.5 & 26.2 & 22.3 & 12 & 32 & 45 & 11 \\
\hline
\end{tabular}

TABLE 2: The chemical compositions of clay.

\begin{tabular}{lcccccc}
\hline $\mathrm{SiO}_{2}$ & $\mathrm{Al}_{2} \mathrm{O}_{3}$ & $\mathrm{Fe}_{2} \mathrm{O}_{3}$ & $\mathrm{CaO}$ & $\mathrm{MgO}$ & $\mathrm{K}_{2} \mathrm{O}$ & $\mathrm{Na}_{2} \mathrm{O}$ \\
\hline $\mathbf{5 8 . 4 2}$ & 25.23 & 0.24 & 0.51 & 0.12 & 5.32 & 2.67 \\
\hline
\end{tabular}

sewage sludge is dehydrated by machinery. On the basis of "Determination Method for Municipal Sludge in Wastewater Treatment Plant" (CJ/T 221-2005), the basic property indexes of sewage sludge are shown in Table 3.

Sewage sludge was kept in a thermostatic temperature dry box at $105^{\circ} \mathrm{C}$ for $24 \mathrm{~h}$. After 24 hours, the sewage sludge was weighed every 2 hours. The weighing of the samples was continued until the quality difference is less than $0.1 \%$ of the total quality. At that time, the samples can be considered to be completely free of water. The samples were broken into pieces and sieved through a 2 -mesh screen. Thereafter, the samples were placed in the muffle furnace. The burning temperature was set at $850^{\circ} \mathrm{C}$. The samples were stirred every 24 hours to achieve even heating [14]. After 1 week, the samples turned into grainy red brown ash. The red brown ash was sieved through a 200-mesh screen and then hermetically sealed for later use. The chemical constituents of sewage sludge ash (SSA) are listed in Table 4. The microstructure, pore volume, and pore size distribution of SSA are shown in Figures 1 and 2. These figures show that the SSA is porous and that every relic has a small volume. The pore volume distribution of SSA is uniform, with a high proportion of $2 \mathrm{~nm}$ to $4 \mathrm{~nm}$ pores.

\subsection{Testing Methods}

2.2.1. Batch Adsorption Tests. The modified clay was composed of $1 \%$ SSA plus $99 \%$ clay or $3 \%$ SSA plus $97 \%$ clay or $5 \%$ SSA plus $95 \%$ clay. Dry soil samples of $12.5 \mathrm{~g}$ were soaked in $50 \mathrm{~mL} \mathrm{~K} \mathrm{Cr}_{2} \mathrm{O}_{7}$ and $\mathrm{PbCl}_{2}$ chemical solutions, respectively. The initial $\mathrm{Cr}(\mathrm{VI})$ and $\mathrm{Pb}(\mathrm{II})$ concentration was $0-300 \mathrm{mg} / \mathrm{L}$. After stirring evenly, the mixture was placed in a water bath instrument under a temperature of $25^{\circ} \mathrm{C}$. The concentration of $\mathrm{Cr}(\mathrm{VI})$ and $\mathrm{Pb}(\mathrm{II})$ in the suspension solution after centrifugation was measured by spectrophotometry (Shanghai Third Analytical Instruments Factory) according to GB 746787 DPC. The error of the colorimetric measurements was less than $4 \%$. Each batch test was repeated three times.

The concentration of heavy metal ions adsorbed on the soil was calculated from the mass balance:

$$
C_{s}=\frac{\left(C_{0}-C_{e}\right) V}{M}
$$

where $C_{s}$ is the amount of $\mathrm{Cr}(\mathrm{VI})$ and $\mathrm{Pb}(\mathrm{II})$ adsorbed onto the soil samples, $C_{0}$ is the initial concentration of $\mathrm{Cr}(\mathrm{VI})$ and $\mathrm{Pb}(\mathrm{II}), C_{e}$ is equilibrium aqueous concentration of $\mathrm{Cr}(\mathrm{VI})$

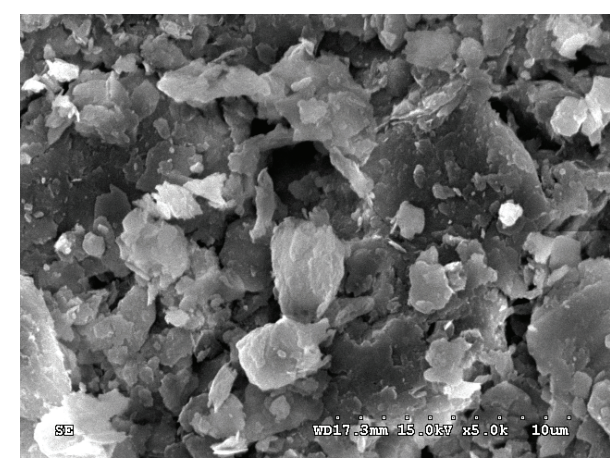

Figure 1: The microstructure of SSA.

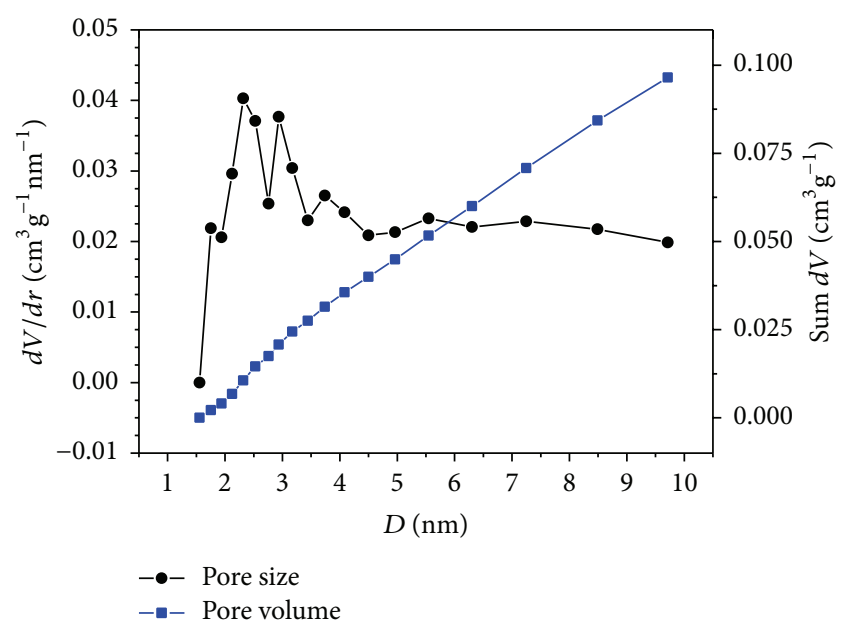

FIGURE 2: The pore volume and pore size distributions of SSA.

and $\mathrm{Pb}(\mathrm{II}), V$ is the volume of the aqueous phase, and $M$ is the weight of the soil samples.

2.2.2. The Low Temperature $\mathrm{N}_{2}$ Adsorption Tests. Modified clay containing 3\% SSA polluted by 0,100 , and $250 \mathrm{mg} / \mathrm{L}$ of $\mathrm{Cr}(\mathrm{VI})$ and $\mathrm{Pb}(\mathrm{II})$ solutions was used in this test. The samples of $0.2 \mathrm{~g}$ were used in the low temperature $\mathrm{N}_{2}$ adsorption tests. The JW-BK static $\mathrm{N}_{2}$ adsorption instrument was used to test the pore structure of the sample. The absorbing medium of the test was $99.99 \% \mathrm{~N}_{2}$, and the sample was kept at liquid nitrogen saturation temperature. The relative pressure $P / P_{0}$ ranged from 0.01 to 0.995 . The sample was adsorbed and desorbed isothermally at 22 pressure points. The specific surface area, the pore volume, and pore size distribution of samples were calculated according to the standard BET method [15]. 
TABLE 3: The basic physical property indexes of sewage sludge.

\begin{tabular}{lcccccc}
\hline $\mathrm{pH}$ & Proportion $(\mathrm{g} / \mathrm{mL})$ & $\begin{array}{c}\text { Organic } \\
\text { matter } \\
\text { content }(\%)\end{array}$ & $\begin{array}{c}\text { Moisture } \\
\text { content }(\%)\end{array}$ & Void ratio & Permeability coefficient $(\mathrm{cm} / \mathrm{s})$ & Compressive strength $\left(\mathrm{kg} / \mathrm{cm}^{2}\right)$ \\
\hline 6.96 & 1.24 & 43.2 & 80.3 & 3.36 & $1.20 \times 10^{-8}$ & 0.068 \\
\hline
\end{tabular}

TABLE 4: The chemical properties of SSA.

\begin{tabular}{ccccccccccc}
\hline $\mathrm{SiO}_{2}$ & $\mathrm{Al}_{2} \mathrm{O}_{3}$ & $\mathrm{Fe}_{2} \mathrm{O}_{3}$ & $\mathrm{CaO}$ & $\mathrm{SO}_{3}$ & $\mathrm{P}_{2} \mathrm{O}_{5}$ & $\mathrm{~K}_{2} \mathrm{O}$ & $\mathrm{MgO}$ & $\mathrm{TiO}_{2}$ & $\mathrm{Na}_{2} \mathrm{O}$ & $\mathrm{O}$ thers \\
\hline $45.5 \%$ & $16.6 \%$ & $8.11 \%$ & $6.64 \%$ & $6.61 \%$ & $5.72 \%$ & $4.45 \%$ & $3.90 \%$ & $0.98 \%$ & $0.83 \%$ & $0.66 \%$ \\
\hline
\end{tabular}

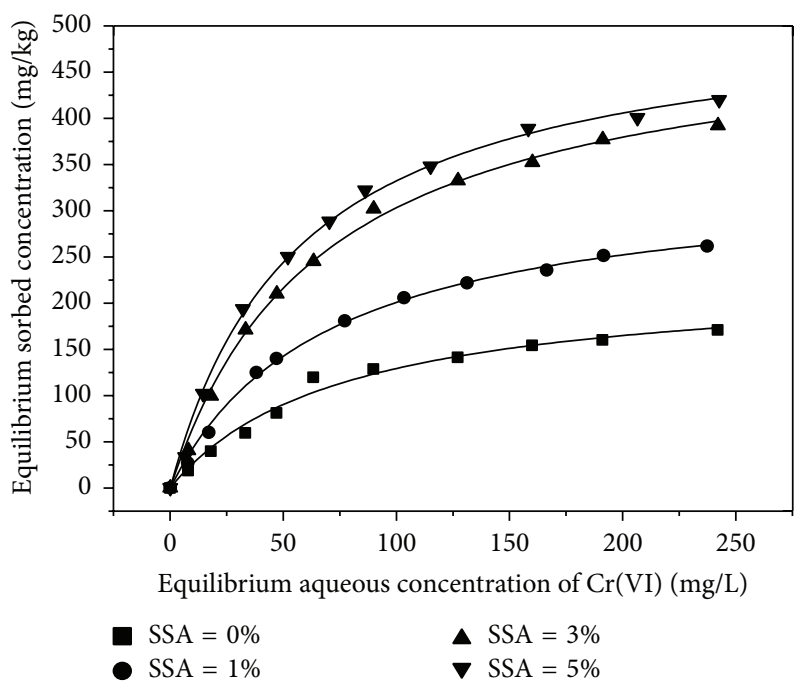

FIgURE 3: The adsorption isotherm for $\mathrm{Cr}(\mathrm{VI})$ with modified clay.

2.2.3. TG-DTA Tests. The samples were the same to the low temperature $\mathrm{N}_{2}$ adsorption tests. Thermal gravimetric and differential thermal analyzer (Beijing Henven Scientific Instrument Factory) was used to test the endothermicexothermic reaction, thermostability, and components of the sample. The temperature range of the thermal analyzer was $0 \sim 1000^{\circ} \mathrm{C}$ and the heating rate was controlled at $10^{\circ} \mathrm{C} / \mathrm{min}$.

\section{Results and Discussion}

3.1. Absorption Capacity. The adsorption isotherm for $\mathrm{Cr}(\mathrm{VI})$ and $\mathrm{Pb}$ (II) with modified clay are shown in Figures 3 and 4, and all adsorptions belong to the Langmuir isotherm model. The adsorption of $\mathrm{Cr}(\mathrm{VI})$ and $\mathrm{Pb}(\mathrm{II})$ onto the soil specimens was modeled as a Langmuir isotherm [16]. The values of the isotherm parameters are given in Table 5. With the content of SSA increasing from $0 \%$ to $3 \%$, the adsorption capacity of $\mathrm{Cr}(\mathrm{VI})$ and $\mathrm{Pb}(\mathrm{II})$ to the modified clay increases dramatically. But when the content of SSA increased from 3\% to 5\%, the adsorption capacity shows a slow increase tendency. At $C_{0}$ being $250 \mathrm{mg} / \mathrm{L}$, the adsorption of $\mathrm{Cr}(\mathrm{VI})$ and $\mathrm{Pb}(\mathrm{II})$ to modified clay containing $3 \%$ SSA is 392.25 and $602.04 \mathrm{mg} / \mathrm{kg}$; these values were 2.30 or 1.88 times greater than that of the raw clay, respectively. SSA has loose structure and large porosity or specific surface area [17]. Hence, ionic charge can
TABle 5: The isotherm parameter for $\mathrm{Cr}(\mathrm{VI})$ and $\mathrm{Pb}(\mathrm{II})$ with modified clay.

\begin{tabular}{lccccc}
\hline Ions & & $0 \%$ & $1 \%$ & $3 \%$ & $5 \%$ \\
\hline \multirow{3}{*}{$\mathrm{Cr}(\mathrm{VI})$} & $b(\mathrm{~L} / \mathrm{mg})$ & 0.013 & 0.015 & 0.015 & 0.016 \\
& $q_{m}(\mathrm{mg} / \mathrm{kg})$ & 227.80 & 339.10 & 507.51 & 520.38 \\
& $R^{2}$ & 0.986 & 0.998 & 0.997 & 0.997 \\
\hline \multirow{3}{*}{$\mathrm{Pb}(\mathrm{II})$} & $b(\mathrm{~L} / \mathrm{mg})$ & 0.006 & 0.011 & 0.015 & 0.014 \\
& $q_{m}(\mathrm{mg} / \mathrm{kg})$ & 557.33 & 601.20 & 773.26 & 827.15 \\
& $R^{2}$ & 0.992 & 0.996 & 0.997 & 0.997 \\
\hline
\end{tabular}

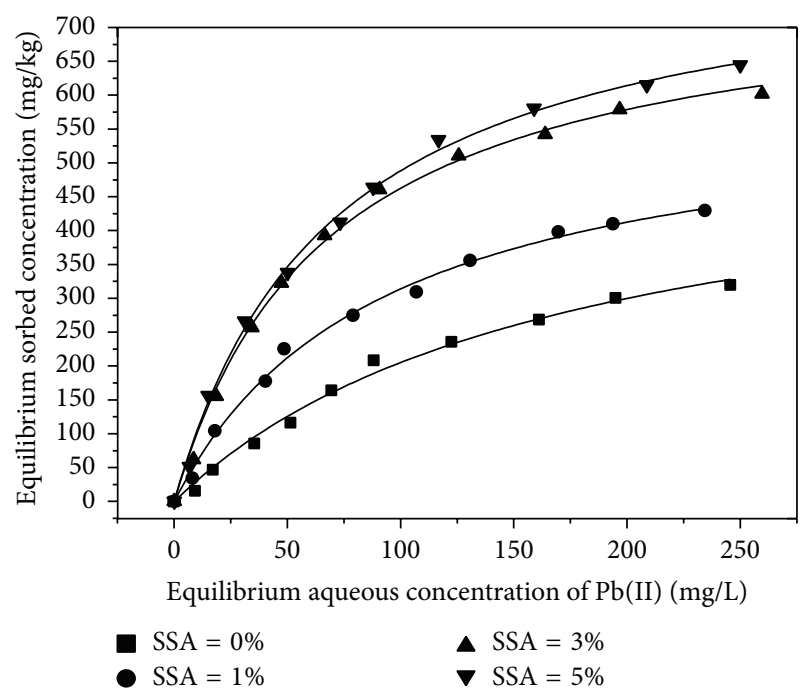

FIGURE 4: The adsorption isotherm for $\mathrm{Pb}(\mathrm{II})$ with modified clay.

be adsorbed on the surface of SSA debris in the adsorption process. A large number of metal ions absorbed to the surface of the debris, resulting in a positive charge presented in debris. The heavy metal ion adsorption capacity of the debris gradually decreases under the action of Coulomb repulsion.

3.2. Pore Structure. The adsorption and desorption isotherm of the samples are shown in Figure 5. According to IUPAC classification, the isotherm is IV category. There is a $\mathrm{H}_{3}$ hysteresis loop in the process of adsorption and desorption [18]. The bottle shaped pore of the soil is rough, and absorbed $\mathrm{N}_{2}$ can be easily blocked in the orifice. Thus, $\mathrm{N}_{2}$ cannot overflow completely in the desorption process [19]. 


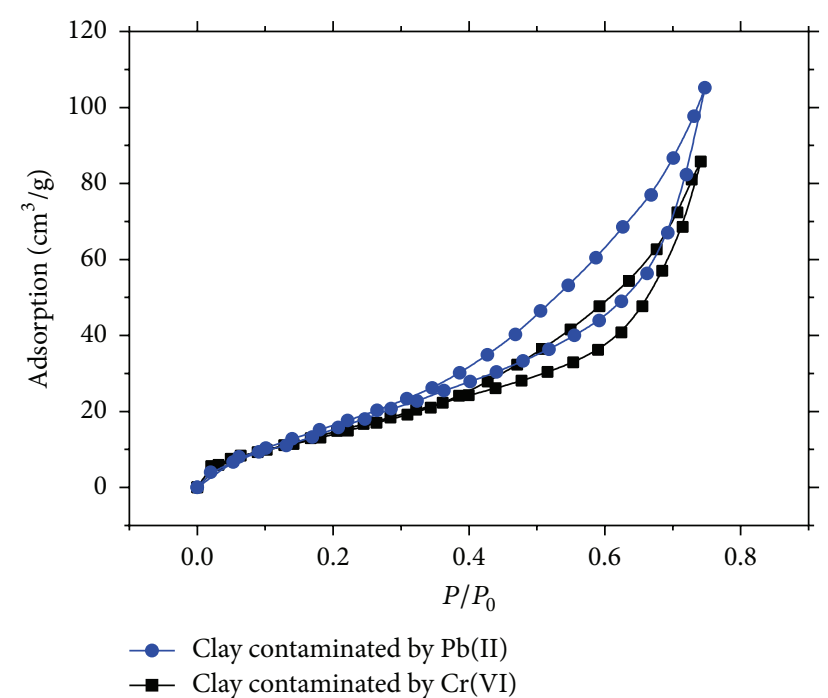

FIGURE 5: Adsorption and desorption isotherm of the samples.

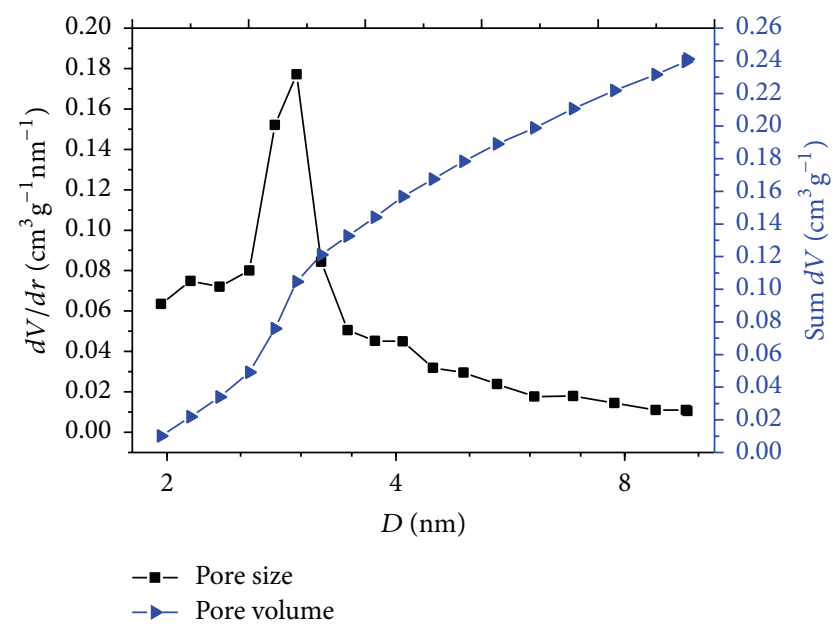

FIGURE 6: The pore volume and pore size distributions of modified clay $\left(C_{0}=0 \mathrm{mg} / \mathrm{L}\right)$.

The pore volume and pore size distribution of modified clay are shown in Figures 6-8. The pore distribution of modified clay is mostly in the range of mesoporous pore size $(2 \sim 8 \mathrm{~nm})$ [20]. In the $2.5 \sim 3.5 \mathrm{~nm}$ range, the peak value of the mesopore is relatively large. After $\mathrm{Pb}$ (II) and $\mathrm{Cr}(\mathrm{VI})$ being absorbed by the samples, the proportion of the mesopore $(2 \sim 2.5 \mathrm{~nm})$ increases, and the number of mesopore $(>3.5 \mathrm{~nm})$ decreased. At the same time, the double peak phenomenon occurs.

The pore parameter of samples can be seen at Table 6 . The relation between the pore parameter and adsorption capacity of $\mathrm{Pb}(\mathrm{II})$ and $\mathrm{Cr}(\mathrm{VI})$ can be seen in Figure 9. The total pore volume dramatically decreased to stable values with increasing adsorption capacity. The specific surface area shows the opposite trend. Ions will be closely packed on the inner wall of pore in the adsorption process, resulting in increasing of the inner wall surface roughness and decreasing the total pore volume.

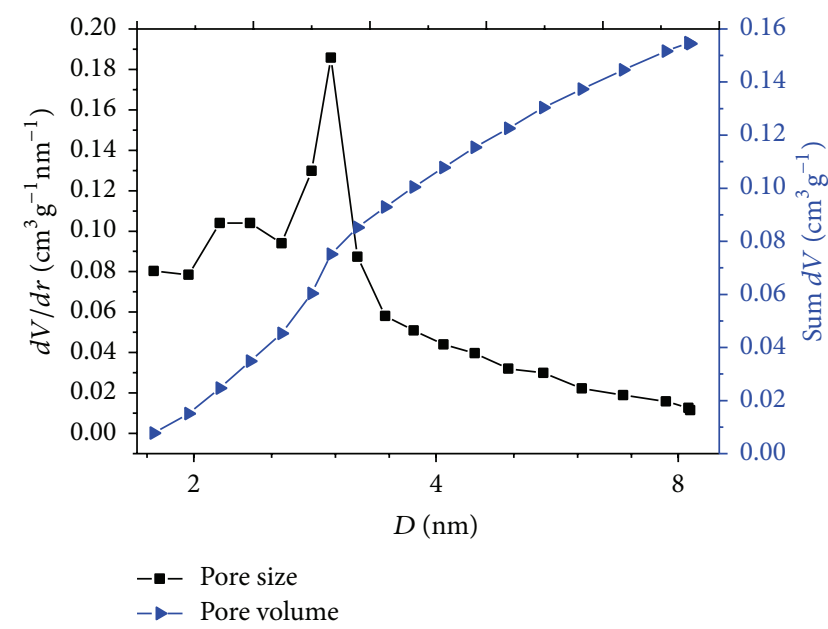

(a) $C_{0}=100 \mathrm{mg} / \mathrm{L}$

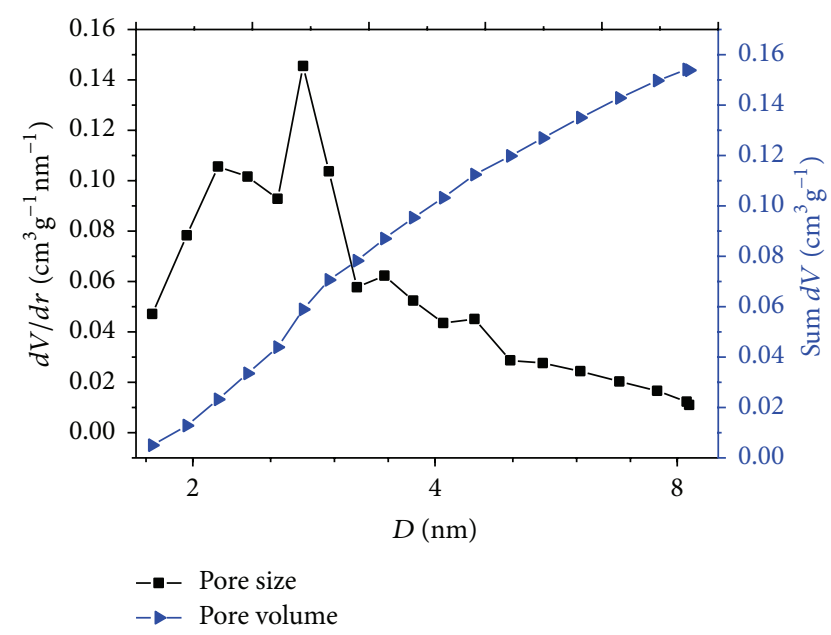

(b) $C_{0}=250 \mathrm{mg} / \mathrm{L}$

FIGURE 7: The pore volume and pore size distributions of modified clay after absorbing $\mathrm{Cr}(\mathrm{VI})$.

3.3. Thermostability and Components. The DTG-T curves of samples are shown in Figure 10. The weight loss of the samples is shown in Table 7. Due to the removal of free water and weakly bound water in samples, there is an obvious weight loss valley at $25 \sim 250^{\circ} \mathrm{C}$. Another weight loss valley appears at $400 \sim 700^{\circ} \mathrm{C}$ owing to the reduction reaction of metal ions. The weight loss valley becomes obvious with the increasing of adsorption capacity of $\mathrm{Cr}(\mathrm{VI})$ and $\mathrm{Pb}$ (II) onto the samples. Metal ions need absorb heat to obtain electrons in the process of reduction reaction [21]. The valence of $\mathrm{Cr}(\mathrm{VI})$ and $\mathrm{Pb}$ (II) declines and they transformed into mental element. The maximum temperature is $1000^{\circ} \mathrm{C}$ in the test. The temperature did not reach the melting point of $\mathrm{Cr}$ or $\mathrm{Pb}$ element. Metal elements are closely attached to the soil particles. At 700 $1000^{\circ} \mathrm{C}$, the material decomposition reaction is gradually completed, and the weight loss of samples is less than $0.2 \%$.

The DTA-T curves of the samples are shown in Figure 11. The endothermic valley and the exothermic peak are shown in the DTA-T curve. The absorption valley of the curve will appear, indicating the samples need absorb heat in 
TABle 6: Pore parameter of the samples.

\begin{tabular}{|c|c|c|c|c|}
\hline Sample classification & $\begin{array}{l}\text { Initial concentration } \\
\text { of } \mathrm{Cr}(\mathrm{VI}) \text { and } \mathrm{Pb}(\mathrm{II})\end{array}$ & $\begin{array}{l}\text { The total pore } \\
\text { volume }\left(\mathrm{cm}^{3} / \mathrm{g}\right)\end{array}$ & $\begin{array}{l}\text { Average pore } \\
\text { size }(\mathrm{nm})\end{array}$ & $\begin{array}{c}\text { Specific } \\
\text { surface area } \\
\left(\mathrm{m}^{2} / \mathrm{g}\right)\end{array}$ \\
\hline Modified clay & $0 \mathrm{mg} / \mathrm{L}$ & 0.241 & 5.673 & 104.98 \\
\hline \multirow{2}{*}{ Modified clay after absorbing $\mathrm{Cr}(\mathrm{VI})$} & $100 \mathrm{mg} / \mathrm{L}$ & 0.154 & 5.086 & 107.17 \\
\hline & $250 \mathrm{mg} / \mathrm{L}$ & 0.147 & 5.038 & 118.60 \\
\hline \multirow{2}{*}{ Modified clay after absorbing $\mathrm{Pb}(\mathrm{II})$} & $100 \mathrm{mg} / \mathrm{L}$ & 0.145 & 4.718 & 126.20 \\
\hline & $250 \mathrm{mg} / \mathrm{L}$ & 0.139 & 4.655 & 137.14 \\
\hline
\end{tabular}

TABLE 7: Percentage of weight loss.

\begin{tabular}{lccccc}
\hline Anaerobic fermentation & $25 \sim 250^{\circ} \mathrm{C}$ & $250 \sim 400^{\circ} \mathrm{C}$ & $400 \sim 700^{\circ} \mathrm{C}$ & $>700^{\circ} \mathrm{C}$ & $0.19 \%$ \\
\hline $0 \mathrm{mg} / \mathrm{L}$ & $9.40 \%$ & $0.46 \%$ & $2.69 \%$ & $0.15 \%$ & $12.74 \%$ \\
$C_{\mathrm{Cr}(\mathrm{VI})}=100 \mathrm{mg} / \mathrm{L}$ & $9.34 \%$ & $0.60 \%$ & $2.82 \%$ & $0.06 \%$ & $12.91 \%$ \\
$C_{\mathrm{Cr}(\mathrm{VI})}=250 \mathrm{mg} / \mathrm{L}$ & $11.47 \%$ & $0.54 \%$ & $3.32 \%$ & $0.15 \%$ & $15.39 \%$ \\
$C_{\mathrm{Pb}(\mathrm{II})}=100 \mathrm{mg} / \mathrm{L}$ & $9.32 \%$ & $0.46 \%$ & $2.78 \%$ & $0.16 \%$ & $12.71 \%$ \\
$C_{\mathrm{Pb}(\mathrm{II})}=250 \mathrm{mg} / \mathrm{L}$ & $10.63 \%$ & $0.45 \%$ & $3.03 \%$ & & $14.27 \%$ \\
\hline
\end{tabular}

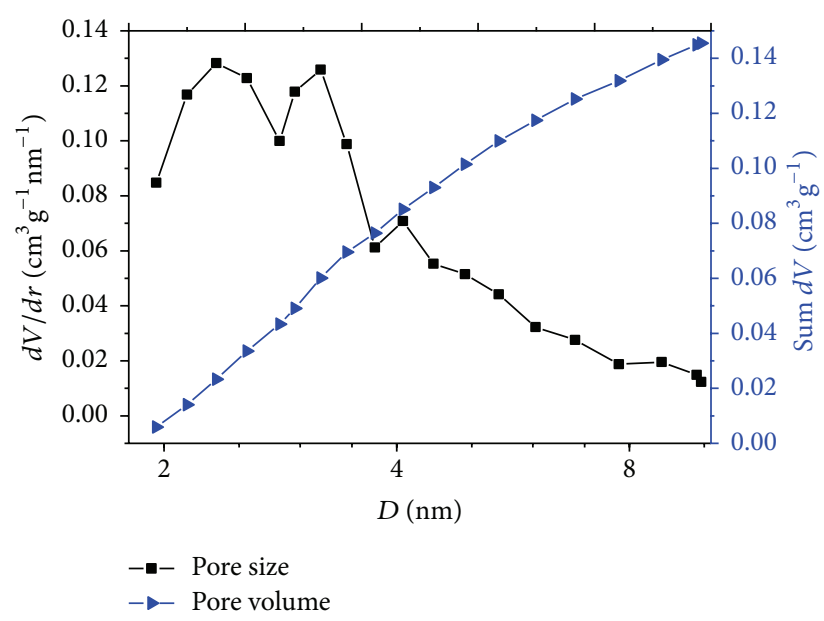

(a) $C_{0}=100 \mathrm{mg} / \mathrm{L}$

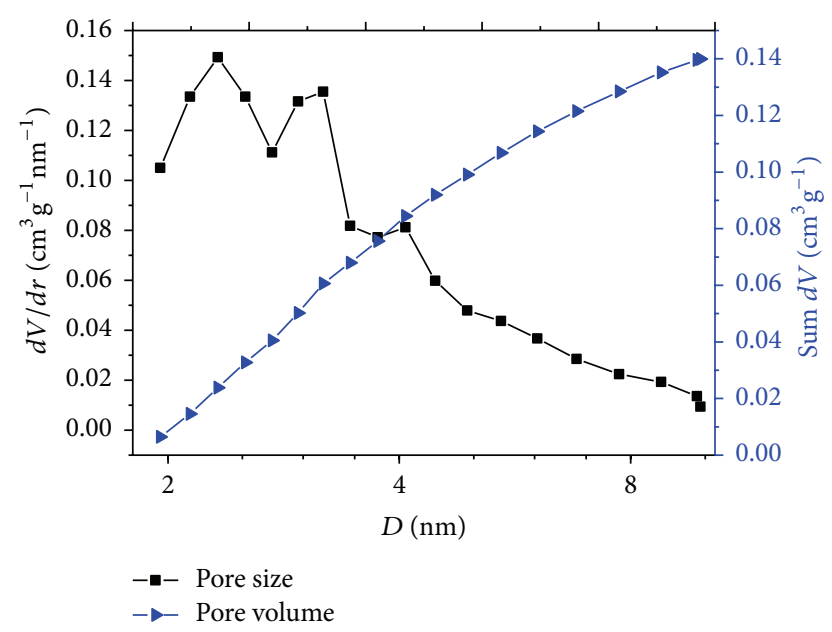

(b) $C_{0}=250 \mathrm{mg} / \mathrm{L}$

FIGURE 8: The pore volume and pore size distributions of modified clay after absorbing $\mathrm{Pb}(\mathrm{II})$.

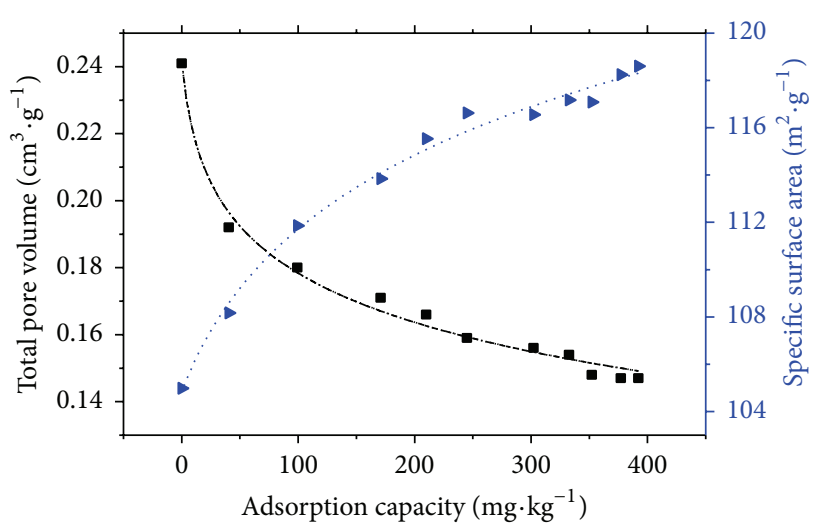

(a) $\mathrm{Cr}(\mathrm{VI})$

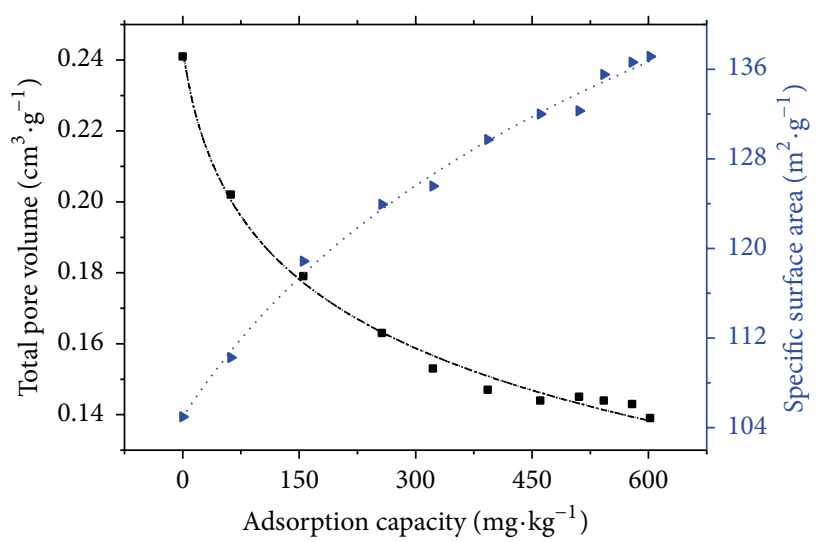

(b) $\mathrm{Pb}(\mathrm{II})$

FIGURE 9: Adsorption equilibrium concentration and parameter variation curve of pore structure.

the dehydration. An exothermic peak can be found in the combustion and oxidative cleavage reaction. Because of the dehydration reaction of free water and weakly bound water, 


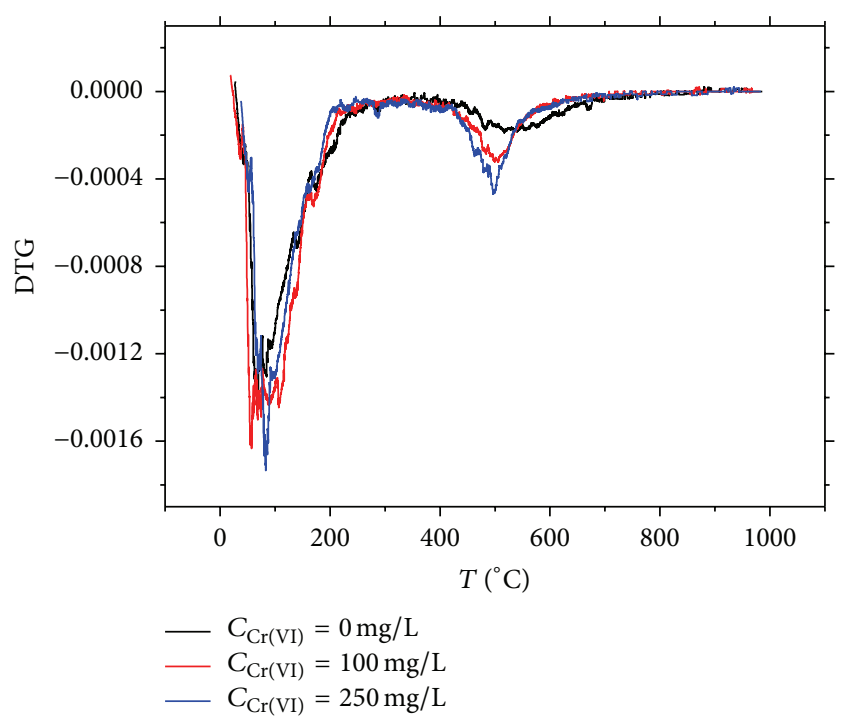

(a) $\mathrm{Cr}(\mathrm{VI})$

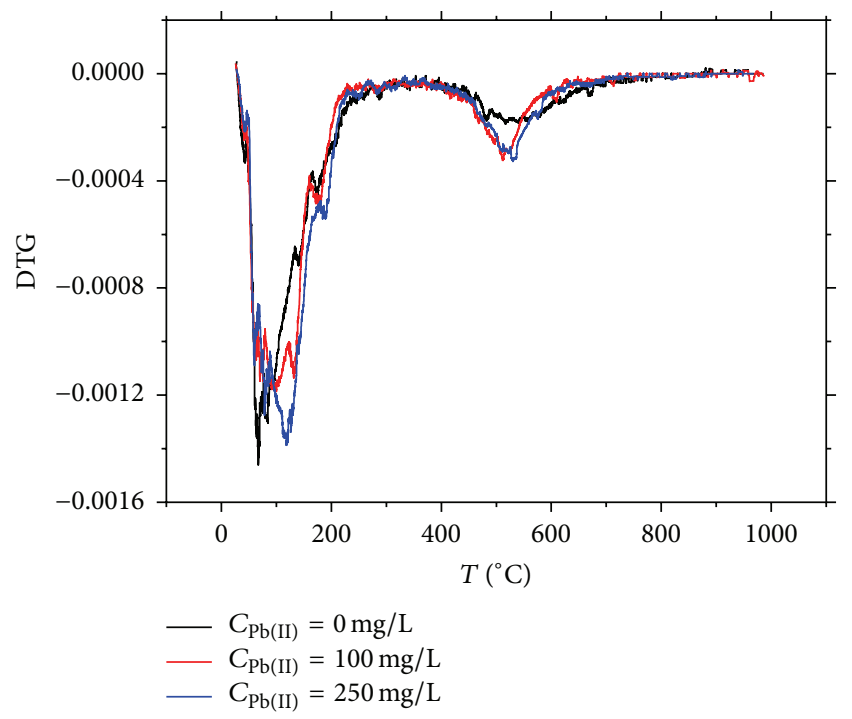

(b) $\mathrm{Pb}(\mathrm{II})$

FIGURE 10: Derivation thermogravimetry curvilinear (DTG/TG-T curvilinear).

a large endothermic valley will appear at $25 \sim 250^{\circ} \mathrm{C}$. Another endothermic valley occurs owing to reduction reaction of metal ions at $400 \sim 700^{\circ} \mathrm{C}$.

\section{Conclusions}

To evaluate the feasibility of modified clay containing SSA as a new landfill liner-soil material, the adsorption capacity of $\mathrm{Cr}(\mathrm{VI})$ and $\mathrm{Pb}(\mathrm{II})$ to modified clay was observed by the batch adsorption tests. The pore structure, thermostability, and components of the modified clay were observed by low temperature $\mathrm{N}_{2}$ adsorption tests and TG-DTA tests. Based on these experiments the following conclusions can be drawn:

(1) The adsorption capacity of $\mathrm{Cr}(\mathrm{VI})$ and $\mathrm{Pb}(\mathrm{II})$ onto modified clay containing SSA was more obvious than

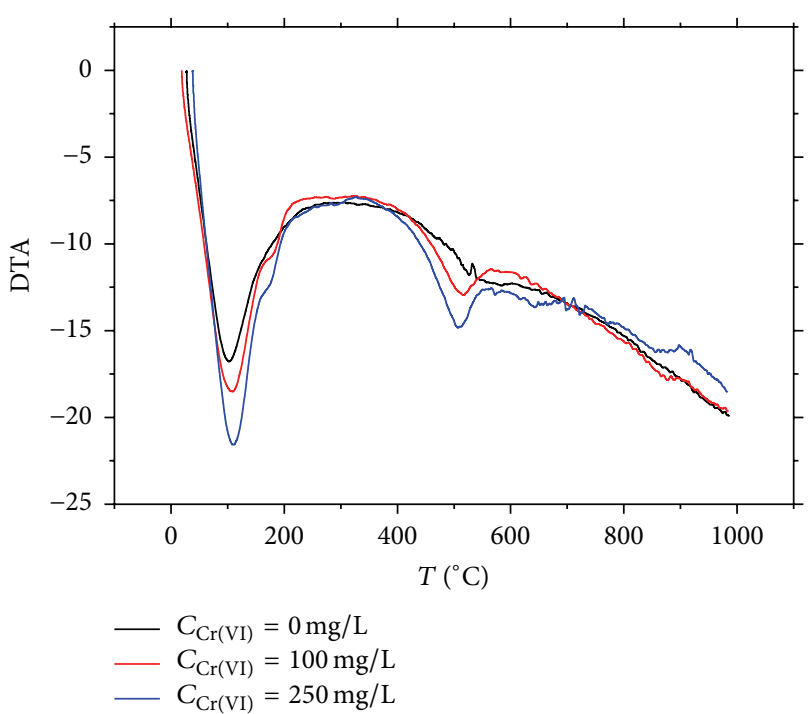

(a) $\mathrm{Cr}(\mathrm{VI})$

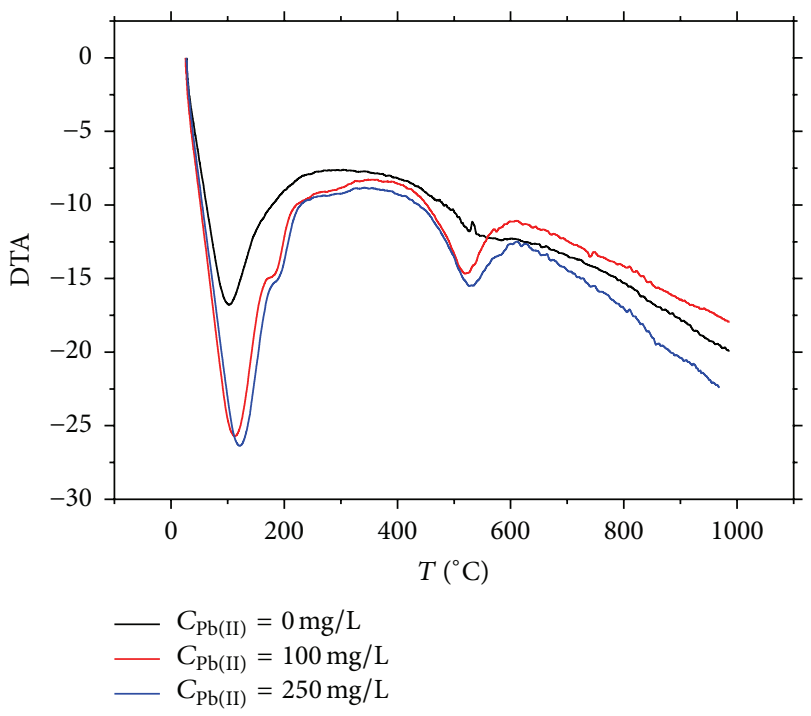

(b) $\mathrm{Pb}$ (II)

FIgURE 11: Differential thermal analysis curvilinear (DTA-T curvilinear).

that of raw clay. The adsorption model is Langmuir isotherm.

(2) The adsorption and desorption isotherms of modified clay polluted by $\mathrm{Cr}(\mathrm{VI})$ and $\mathrm{Pb}(\mathrm{II})$ belong to $\mathrm{IV}$ category, and an $\mathrm{H}_{3}$ hysteresis loop exists. The pores of the samples are mainly composed of the mesopore $(2 \sim 8 \mathrm{~nm})$. With the increasing of adsorption capacity, the pore volume dramatically decreases to certain value, and the specific surface area increases.

(3) Due to the removal of free water or weakly bound water and the reduction reaction of metal ions, the DTG-T or DTA-T curves of the samples show two obvious weight loss or endothermic valley at 25 $250^{\circ} \mathrm{C}$ and $400 \sim 700^{\circ} \mathrm{C}$, respectively. 
(4) SSA is a kind of potential material for use as sorptive amendment for trapping heavy metals in clay landfill liners.

\section{Competing Interests}

The authors declare that they have no competing interests.

\section{Acknowledgments}

The authors would like to express their great appreciation for funding provided by the "National Natural Science Foundation of China (51474168)", the "Open Research Fund of State Key Laboratory of Geomechanics and Geotechnical Engineering, Institute of Rock and Soil Mechanics, Chinese Academy of Sciences (Z014007)", and the "100 Gifted People Plan of Hubei Province, China."

\section{References}

[1] P.-J. He, Z. Xiao, L.-M. Shao, J.-Y. Yu, and D.-J. Lee, "In situ distributions and characteristics of heavy metals in full-scale landfill layers," Journal of Hazardous Materials, vol. 137, no. 3, pp. 1385-1394, 2006.

[2] A. Giannis, G. Makripodis, F. Simantiraki, M. Somara, and E. Gidarakos, "Monitoring operational and leachate characteristics of an aerobic simulated landfill bioreactor," Waste Management, vol. 28, no. 8, pp. 1346-1354, 2008.

[3] X. Qu, P.-J. He, L.-M. Shao, and D.-J. Lee, "Heavy metals mobility in full-scale bioreactor landfill: initial stage," Chemosphere, vol. 70, no. 5, pp. 769-777, 2008.

[4] J.-L. Zhang, M.-T. Luan, and Q. Yang, "Numerical analysis of transport of landfill pollutants in unsaturated soil layer," Chinese Journal of Geotechnical Engineering, vol. 28, no. 2, pp. 221-224, 2006.

[5] H. J. Lu, M. T. Luan, and J. L. Zhang, "Study on transport of $\mathrm{Cr}(\mathrm{VI})$ through the landfill liner composed of two-layer soils," Desalination, vol. 266, no. 1-3, pp. 87-92, 2011.

[6] H. Lu, M. Luan, and J. Zhang, "Transport of Cr(VI) through clay liners containing activated carbon or acid-activated bentonite," Applied Clay Science, vol. 50, no. 1, pp. 99-105, 2010.

[7] S. J. Hang, X. D. Liu, and P. Liang, "Misunderstanding of sludge disposal and treatment and control strategy," China Water \& Wastewater, vol. 20, no. 12, pp. 89-92, 2004.

[8] P. Chen, L. T. Zhan, and W. Wilson, "Experimental investigation on shear strength and permeability of a deeply dewatered sewage sludge for use in landfill covers," Environmental Earth Sciences, vol. 71, no. 10, pp. 4593-4602, 2014.

[9] A. Biasin, M. Della Zassa, M. Zerlottin, D. Refosco, R. Bertani, and P. Canu, "On the understanding and control of the spontaneous heating of dried tannery wastewater sludge," Waste Management, vol. 34, no. 4, pp. 817-824, 2014.

[10] J. Zou, Y. Dai, K. Pan et al., "Recovery of silicon from sewage sludge for production of high-purity nano-SiO2," Chemosphere, vol. 90, no. 8, pp. 2332-2339, 2013.

[11] H. F. Wang, J. J. Lu, K. F. Chen, and H. L. Duan, "Harmless treatment of used foundry sands and dewatered municipal sludge by microwave," Metalurgija, vol. 54, no. 3, pp. 459-461, 2015.
[12] S. Ghosh, S. Mukherjee, A. Z. Al-Hamdan, and K. R. Reddy, "Efficacy of fine-grained soil as landfill liner material for containment of chrome tannery sludge," Geotechnical and Geological Engineering, vol. 31, no. 2, pp. 493-500, 2013

[13] C. Vogel, R. M. Exner, and C. Adam, "Heavy metal removal from sewage sludge ash by thermochemical treatment with polyvinylchloride," Environmental Science and Technology, vol. 47, no. 1, pp. 563-567, 2013.

[14] R. Li, W. Zhao, Y. Li, W. Wang, and X. Zhu, "Heavy metal removal and speciation transformation through the calcination treatment of phosphorus-enriched sewage sludge ash," Journal of Hazardous Materials, vol. 283, pp. 423-431, 2015.

[15] S. T. Pham and W. Prince, "Effects of carbonation on the specific surface BET of cement mortar measured by two different methods: Nitrogen adsorption and water adsorption," Advanced Materials Research, vol. 931-932, pp. 421-425, 2014.

[16] L. Y. Xie, L. A. Luo, and Z. Li, "Measurement and simulation of adsorption isotherms of VOCs on MAC," Journal of Chemical Industry and Engineering, vol. 57, no. 6, pp. 1357-1363, 2006.

[17] K.-L. Lin, W.-J. Huang, K.-C. Chen, J.-D. Chow, and H.-J. Chen, "Behaviour of heavy metals immobilized by co-melting treatment of sewage sludge ash and municipal solid waste incinerator fly ash," Waste Management and Research, vol. 27, no. 7, pp. 660-667, 2009.

[18] J.-P. Bellat, C. Paulin, M. Jeffroy et al., "Unusual hysteresis loop in the adsorption-desorption of water in $\mathrm{NaY}$ zeolite at very low pressure," Journal of Physical Chemistry C, vol. 113, no. 19, pp. 8287-8295, 2009.

[19] Y. T. Li, S. Y. Liu, X. L. Zhao, H. Chen, and D. Y. Wang, "Effect of straw-bentonite-polyacrylamide composites on nitrogen adsorption of sandy soil," Transactions of the Chinese Society of Agricultural Engineering, vol. 28, no. 7, pp. 111-116, 2012.

[20] D. Z. Borislav, J. C. Jiří, S. Martin, and J. Josef, "Pore classification in the characterization of porous materials: a perspective," Central European Journal of Chemistry, vol. 5, no. 4, pp. 385-395, 2007.

[21] A. Magdziarz and M. Wilk, "Thermogravimetric study of biomass, sewage sludge and coal combustion," Energy Conversion and Management, vol. 75, pp. 425-430, 2013. 

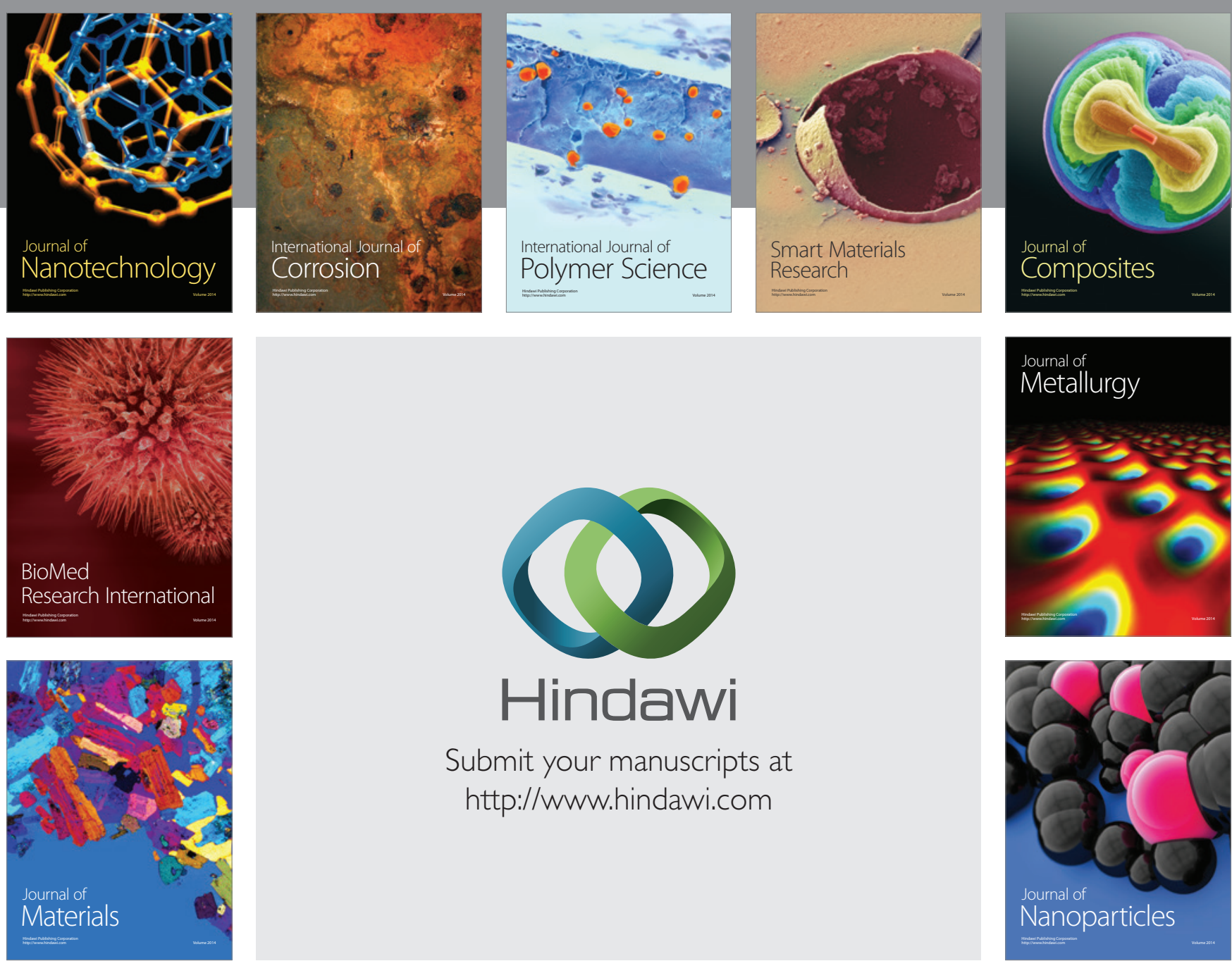

\section{Hindawi}

Submit your manuscripts at

http://www.hindawi.com

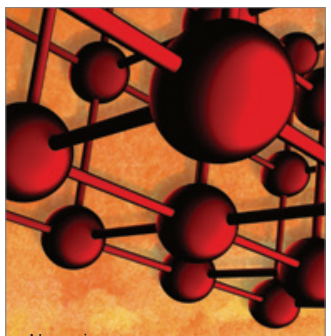

Materials Science and Engineering
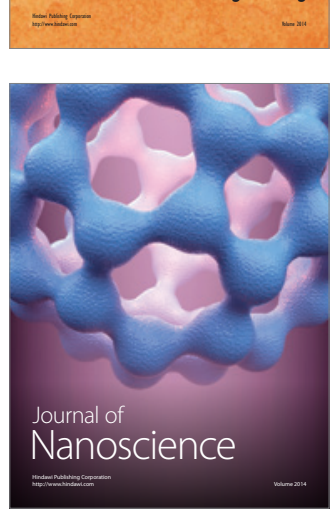
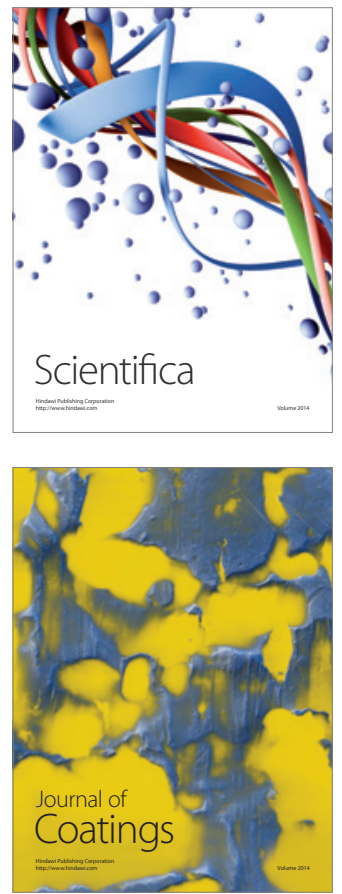
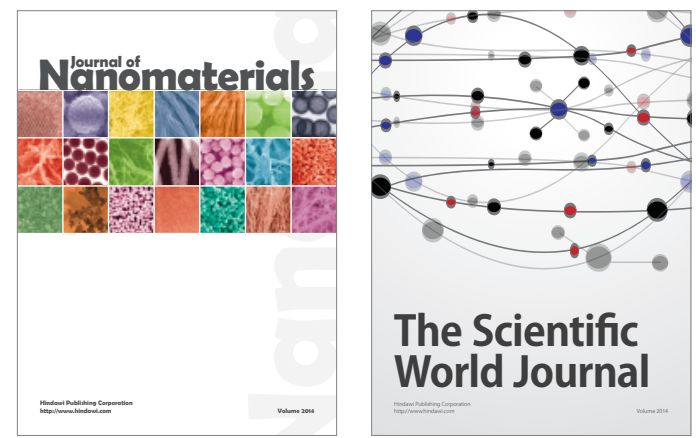

The Scientific World Journal
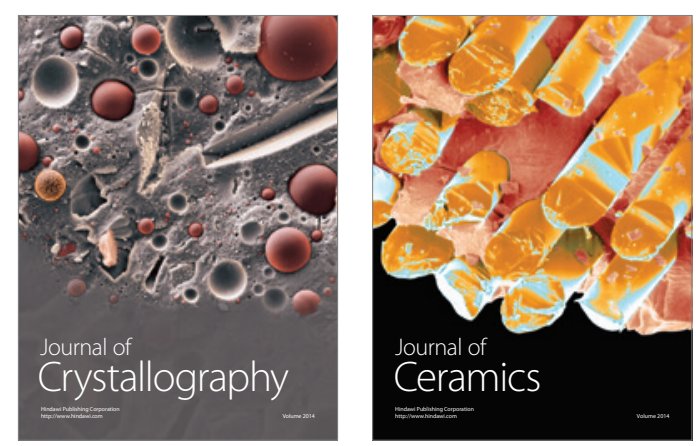
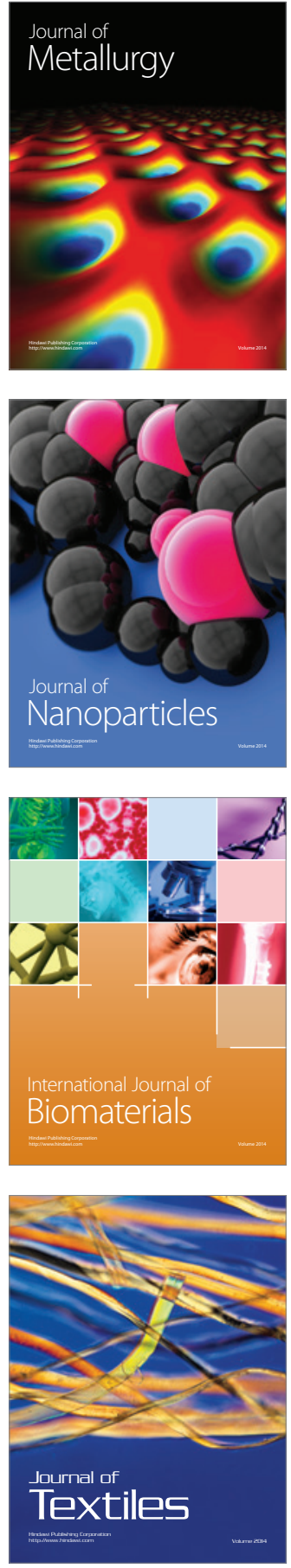